\title{
Geology
}

\section{Proterozoic onset of crustal reworking and collisional tectonics: Reappraisal of the zircon oxygen isotope record}

\author{
Christopher J. Spencer, Peter A. Cawood, Chris J. Hawkesworth, Timothy D. Raub, Anthony R.
} Prave and Nick M.W. Roberts

Geology published online 21 March 2014;

doi: 10.1130/G35363.1

\section{Email alerting services}

\section{Subscribe}

Permission request click www.gsapubs.org/cgi/alerts to receive free e-mail alerts when new articles cite this article

click www.gsapubs.org/subscriptions/ to subscribe to Geology

click http://www.geosociety.org/pubs/copyrt.htm\#gsa to contact GSA

Copyright not claimed on content prepared wholly by U.S. government employees within scope of their employment. Individual scientists are hereby granted permission, without fees or further requests to GSA, to use a single figure, a single table, and/or a brief paragraph of text in subsequent works and to make unlimited copies of items in GSA's journals for noncommercial use in classrooms to further education and science. This file may not be posted to any Web site, but authors may post the abstracts only of their articles on their own or their organization's Web site providing the posting includes a reference to the article's full citation. GSA provides this and other forums for the presentation of diverse opinions and positions by scientists worldwide, regardless of their race, citizenship, gender, religion, or political viewpoint. Opinions presented in this publication do not reflect official positions of the Society.

\section{Notes}

Advance online articles have been peer reviewed and accepted for publication but have not yet appeared in the paper journal (edited, typeset versions may be posted when available prior to final publication). Advance online articles are citable and establish publication priority; they are indexed by GeoRef from initial publication. Citations to Advance online articles must include the digital object identifier (DOIs) and date of initial publication.

(C) Geological Society of America

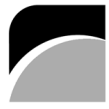

THE GEOLOGICAL SOCIETY 


\title{
Proterozoic onset of crustal reworking and collisional tectonics:
}

\section{Reappraisal of the zircon oxygen isotope record}

\author{
Christopher J. Spencer $^{1 *}$, Peter A. Cawood ${ }^{1}$, Chris J. Hawkesworth ${ }^{1}$, Timothy D. Raub ${ }^{1}$, Anthony R. Prave ${ }^{1}$, and \\ Nick M.W. Roberts² \\ ${ }^{1}$ Department of Earth and Environmental Sciences, University of St Andrews, St Andrews KY16 9AL, UK \\ ${ }^{2}$ NERC Isotope Geosciences Laboratory, British Geological Survey, Keyworth, Nottingham NG12 5GG, UK
}

\begin{abstract}
A global $\mathrm{U}-\mathrm{Pb}$ and $\delta^{18} \mathrm{O}$ zircon database shows temporal changes in the magmatic record related to changes in the degree of crustal reworking. The $\delta^{18} \mathrm{O}$ composition of bulk sediment remains relatively constant through geologic time, with a mean value of $14.9 \%$. In contrast, the $\delta^{18} \mathrm{O}$ values in magmatic zircons vary from relatively low values averaging $\sim 6 \%$ in the Archean to increasingly higher and scattered values defining a series of peaks and troughs in post-Archean data. The degree of crustal reworking increases at times of supercontinent assembly. Therefore we attribute the pattern of post-Archean $\delta^{18} \mathrm{O}$ values recorded by magmatic zircons to a significant increase in the incorporation of high $\delta^{18} \mathrm{O}$ sediment in response to enhanced crustal thickening and reworking associated with the onset of collisional tectonics, especially during formation of supercontinents.
\end{abstract}

\section{INTRODUCTION}

Zircon is physically and chemically stable across a wide range of conditions. Its abundance in felsic and intermediate igneous rocks and refractory nature in sedimentary rocks make it a key mineral to understand the evolution of the continental crust (Hawkesworth and Kemp, 2006; Cawood et al., 2013). At the time of crystallization, oxygen isotopes in zircon reflect the $\delta^{18} \mathrm{O}$ values of the host magma and therefore the relative contributions of material from the mantle and continental crust, with $\delta^{18} \mathrm{O}$ values between $4.7 \%$ and $6.0 \%$ o taken as indicative of the former (Valley et al., 1998; Page et al., 2007; Grimes et al., 2011). Excluding zircons damaged by radiation or thermal dilation (e.g., Cherniak and Watson, 2001; Booth et al., 2005), any significant increase from those mantle values is interpreted as incorporation of supracrustal material (Valley et al., 2005) and results in melts with elevated zircon $\delta^{18} \mathrm{O}$ values (e.g., Valley et al., 1994; Roberts et al., 2013).

To investigate changes in the degree of crustal reworking in continental magmas through time, we compiled a global database of oxygen isotope analyses of zircon (Table DR1 in the GSA Data Repository ${ }^{1}$ ). Previous such studies indicate that Earth's Archean crust was dominated by mantle-like oxygen isotopic values, whereas

\footnotetext{
*Current address: NERC Isotope Geosciences Laboratory, British Geological Survey, Keyworth, Nottingham NG12 5GG, UK; E-mail: spenchristoph@ gmail.com.

${ }^{1}$ GSA Data Repository item 2014158, Table DR1 $\left(\delta^{18} \mathrm{O}\right.$ values in zircon), and Table DR2 (sedimentary proportions model and average $\delta^{18} \mathrm{O}$ compositions of the sedimentary rock types), is available online at www.geosociety.org/pubs/ft2014.htm, or on request from editing@geosociety.org or Documents Secretary, GSA, P.O. Box 9140, Boulder, CO 80301, USA.
}

post-Archean zircons have a greater range in $\delta^{18} \mathrm{O}$ (Valley et al., 2005; Dhuime et al., 2012). It has remained unresolved whether the former signifies minimal crustal reworking or a restricted range of $\delta^{18} \mathrm{O}$ (based on whole-rock analysis) latter reflects increased contribution from upper crustal melts and/or an increasingly evolved supracrustal reservoir available for reworking. Furthermore, it has variably been proposed that the envelope of maximum $\delta^{18} \mathrm{O}$ values in magmatic zircons increases from the Paleoproterozoic to the present (Valley et al., 2005), or that $\delta^{18} \mathrm{O}$ in zircon increased until ca. $1.1 \mathrm{Ga}$ and decreased until the present (Van Kranendonk and Kirkland, 2013).

We reevaluate the extent to which the $\delta^{18} \mathrm{O}$ values of sedimentary rocks have changed through time and compare the $\delta^{18} \mathrm{O}$ values of zircon with that of the sedimentary record. The zircon $\delta^{18} \mathrm{O}$ database presented in Table DR1 highlights an increase in elevated $\delta^{18} \mathrm{O}$ material above an essentially constant Hadean-Archean background between ca. 2.5 and $2.15 \mathrm{Ga}$. This is attributed to the incorporation of low-temperature fractionated supracrustal material during the earliest Proterozoic that we interpret as linked to the onset of significant crustal thickening and continental collisions (e.g., Ernst, 2009; Dhuime et al., 2012; Keller and Schoene, 2012).

\section{METHODS}

Our database combines $\sim 6300 \delta^{18} \mathrm{O}$ analyses of detrital and igneous zircon grains (Figs. 1A and 1B; Table DR1). We exclude data reported from metamorphic grains or overgrowths (which tend to be extremely fractionated; e.g., Bowman et al., 2011) as well as from zircons with $\mathrm{U}-\mathrm{Pb}$ ages $>10 \%$ discordant. The U-Pb age distribution of the data compiled in this study in Archean sedimentary rocks, and whether the is similar to that for the modern river zircon database (Campbell and Allen, 2008) and the database of Voice et al. (2011) of 200,000 zircon $\mathrm{U}-\mathrm{Pb}$ ages. This affirms that our database broadly represents the exposed crustal record, although the extent to which tectonic processes may bias that record remains a subject of debate (Hawkesworth et al., 2010; Condie et al., 2011; Cawood et al., 2013).

Our database differs from that used previously by Valley et al. (2005) in that it incorporates nearly three times the number of analyses and demonstrates (1) a broader range (though statistically equivalent mean) of Archean $\delta^{18} \mathrm{O}$ values, $+2.4 \%$ o to $+8.8 \%$ o (average $=5.9 \%$ o $\pm 0.9 \%$ o $1 \sigma$ ) versus $+2.4 \%$ o to $+7.5 \%$ o (average $=5.8 \% \circ \pm 0.7 \% \circ, 1 \sigma) ;(2)$ unimodal distribution of Proterozoic $\delta^{18} \mathrm{O}$ values (Fig. 2; note the similarity with Phanerozoic values) with low skewness $(\sigma=1.0)$; and (3) $5 \%$ of analyses are above the composition-time envelope of $\delta^{18} \mathrm{O}$ values previously proposed (Valley et al., 2005). We parse and analyze the updated database using a bin-size optimization procedure (Shimazaki and Shinomoto, 2007) to avoid pitfalls associated with bin widths that are unjustifiably small relative to analytical errors (as in Voice et al., 2011), or are so large as to limit interpretive resolution (as in Dhuime et al., 2012).

We have used the natural subdivisions of zircon age frequency within the compiled data set (Fig. 1A) as the basis for evaluating temporal isotopic shifts and to divide the $\delta^{18} \mathrm{O}$ data set into the following time intervals: pre-3100 Ma, 3100-2450 Ma, 2450-2000 Ma, 2000-1600 Ma, 1600-1300 Ma, 1300-900 Ma, and 900-400 Ma (Fig. 2A). We note that values of $\delta^{18} \mathrm{O}$ from zircons with ages younger than $400 \mathrm{Ma}$ are lower than those immediately preceding them (Fig. 1B). This is likely due to the disproportionate sampling of atypical compositions and/or petrotectonic associations for the post-400 Ma data, e.g., the extremely low $\delta^{18} \mathrm{O}$ magmas from the Isle of Skye (Gilliam and Valley, 1997; Monani and Valley, 2001) and Yellowstone (Bindeman and Valley, 2001; Bindeman, 2008). Given these uncertainties and the smaller data set within this timeframe, we do not consider it further in this study.

Zircons from different time periods exhibit different distributions of $\delta^{18} \mathrm{O}$ (Fig. 2B) that can be grouped into two categories (Fig. 2B): type 1 , characterized by a narrow peak between 


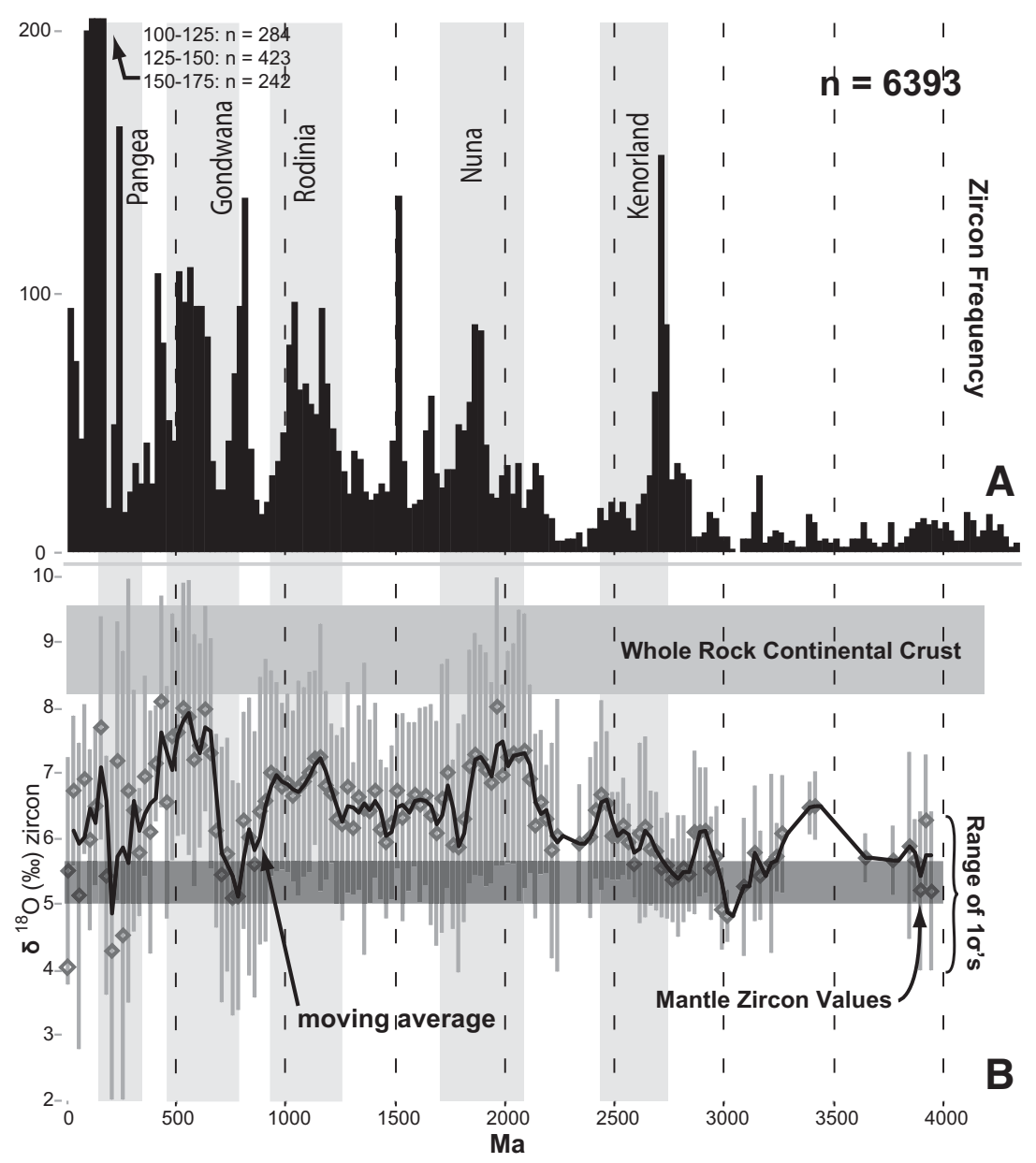

Figure 1. A: Histogram of compiled U-Pb ages with accompanying $\delta^{18} \mathrm{O}$ values overlain on age ranges of supercontinents (see Campbell and Allen, 2008; Bradley, 2011). B: Distilled compilation of $\sim 3300 \delta^{18} \mathrm{O}$ analyses of zircon versus $\mathrm{U}-\mathrm{Pb}$ age plotted as means and standard deviations for 25 m.y. bins. Also plotted are range of average mantle and continental crust values (Valley et al., 1998) and moving average of $\delta^{18} \mathrm{O}$ bins.

$5.5 \%$ and $6.5 \%$ with low variance and skewed toward enriched isotopic values (time intervals 3100-2450, 2450-2000, and 1600-1300 Ma); and type 2 , marked by a broad peak between $6.5 \%$ and $8.0 \%$ with high variance and nearnormal distribution (time intervals 2000-1600, 1300-900, and 900-400 Ma).

The secular change in $\delta^{18} \mathrm{O}$ of zircons from relatively low and constant during the Archean to a systematic increase through the Proterozoic Era and Phanerozoic Eon was explained by Valley et al. (2005) to reflect a shift in the $\delta^{18} \mathrm{O}$ composition of shale through time (see also Land and Lynch, 1996) in addition to an enhanced rate of subduction at the end of the Archean. However, pelitic rocks form only $\sim 40 \%$ of the bulk sediment budget post-3.5 Ga. We have therefore used the relative abundance of different sedimentary rock types and their representative whole-rock $\delta^{18} \mathrm{O}$ compositions (see Eiler, 2001; Valley et al., 2005; Bindeman, 2008) to assess the $\delta^{18} \mathrm{O}$ composition of global bulk sediment through time. We adopt the proportions of sedimentary rocks determined by
Ronov (1964), using a smoothed estimate of present-day distributions preserved within continental interiors (Fig. 3; see also Table DR2). The total preserved mass of sedimentary rock prior to $3 \mathrm{Ga}$ is small, which hinders estimating their proportions; nonetheless, the Ronov (1964) treatment is considered appropriate for broad-scale hypothesis testing. We contrast the proportions proposed by Ronov (1964) with those proposed by K. Condie (2014, personal commun.; see Fig. 3).

Shales, cherts, and carbonate rocks appear to have shifted toward higher $\delta^{18} \mathrm{O}$ values from the Archean to the present by 3\%o-5\%o (Land and Lynch, 1996; Shields and Veizer, 2002; Perry and Lefticariu, 2003; Knauth, 2005), whereas sandstones and submarine volcanogenic rocks have remained nearly constant (Kolodny and Epstein, 1976; Anderson and Arthur, 1983; Eiler, 2001). Assuming that the relative proportions of these lithologies are representative of global sedimentary rock volumes through time, their integrated isotopic composition can be estimated. Although Figure 3 does not illustrate the preservation bias of large sedimentary packages (Bradley, 2008), it highlights overall temporal trends (Veizer and Mackenzie, 2003) and reveals a relatively constant average of $14.9 \%$ o $\pm 1.0 \%$ o $(2 \sigma) \delta^{18} \mathrm{O}$ for bulk continental sediment from the Archean through Phanerozoic. This implies that the extent of fractionation of ${ }^{18} \mathrm{O}$ within the sedimentary environment has not changed significantly since the Archean.

We evaluate temporal changes in supracrustal input at a resolution that divides the data set into 25 m.y. bins (bin width optimization parameters of Shimazaki and Shinomoto, 2007, suggest 23.1 m.y.). We then use the average $\delta^{18} \mathrm{O}$ bulk sediment (14.9\%o, discussed herein) and mantle (whole rock) values (5.5\%o; Bindeman, 2008) as end members of a mixing trend to parameterize what is termed the "reworking index" (Fig. 4). Our results show a subdued moving average with relatively minor variation in crustal reworking from ca. 4.0 to $2.5 \mathrm{Ga}$, but a marked increase in reworking after $2.5 \mathrm{Ga}$ accompanied by a pulsed pattern of sequential increases bounded by abrupt decreases at $1800 \mathrm{Ma}, 850 \mathrm{Ma}$, and 350 Ma (Fig. 4).

\section{DISCUSSION}

The patterns of peaks and troughs in zircon $\delta^{18} \mathrm{O}$ values (Fig. 4) broadly coincide with zircon age distribution profiles, excluding the ca. 2.7 Ga U-Pb age peak, which has subdued $\delta^{18} \mathrm{O}$ values (Fig. 1A). Pre-2.5 Ga zircons define type $1 \delta^{18} \mathrm{O}$ distributions (Fig. 2B), with means near to mantle values and limited crustal reworking. Type 2 distributions (Fig. 2B), in contrast, have means at higher $\delta^{18} \mathrm{O}$ values and indicate that the post-2.5 Ga peaks in zircon age frequency are correlative to greater crustal reworking and harbingers of supercontinent tectonics. This is likely an outcome of continental collision and times of increased preservation of continental crust. After the initial formation of substantial crustal blocks, the geodynamics of plate convergence through time increasingly involved continental collisions accompanied by significant crustal reworking, leading to isotope ratios that deviate from depleted mantle compositions (see also Hawkesworth et al., 2010; Cawood et al., 2013). These findings cast doubt on the hypothesis that zircon age frequency is associated with increased juvenile crustal generation during mantle overturn or plume events (Stein and Hofmann, 1994; Rino et al., 2004; Stein and Ben-Avraham, 2007; Arndt and Davaille, 2013).

The onset of modern plate tectonics is thought to have begun by the Neoarchean (Cawood et al., 2006; Ernst, 2009; Condie and Kröner, 2013; Dhuime et al., 2012). The earliest subduction zones were likely dominated by the formation and accretion of oceanic arcs accompanied by minimal crustal reworking and significant recycling into the mantle (Condie and Kröner, 2013). Over time con- 


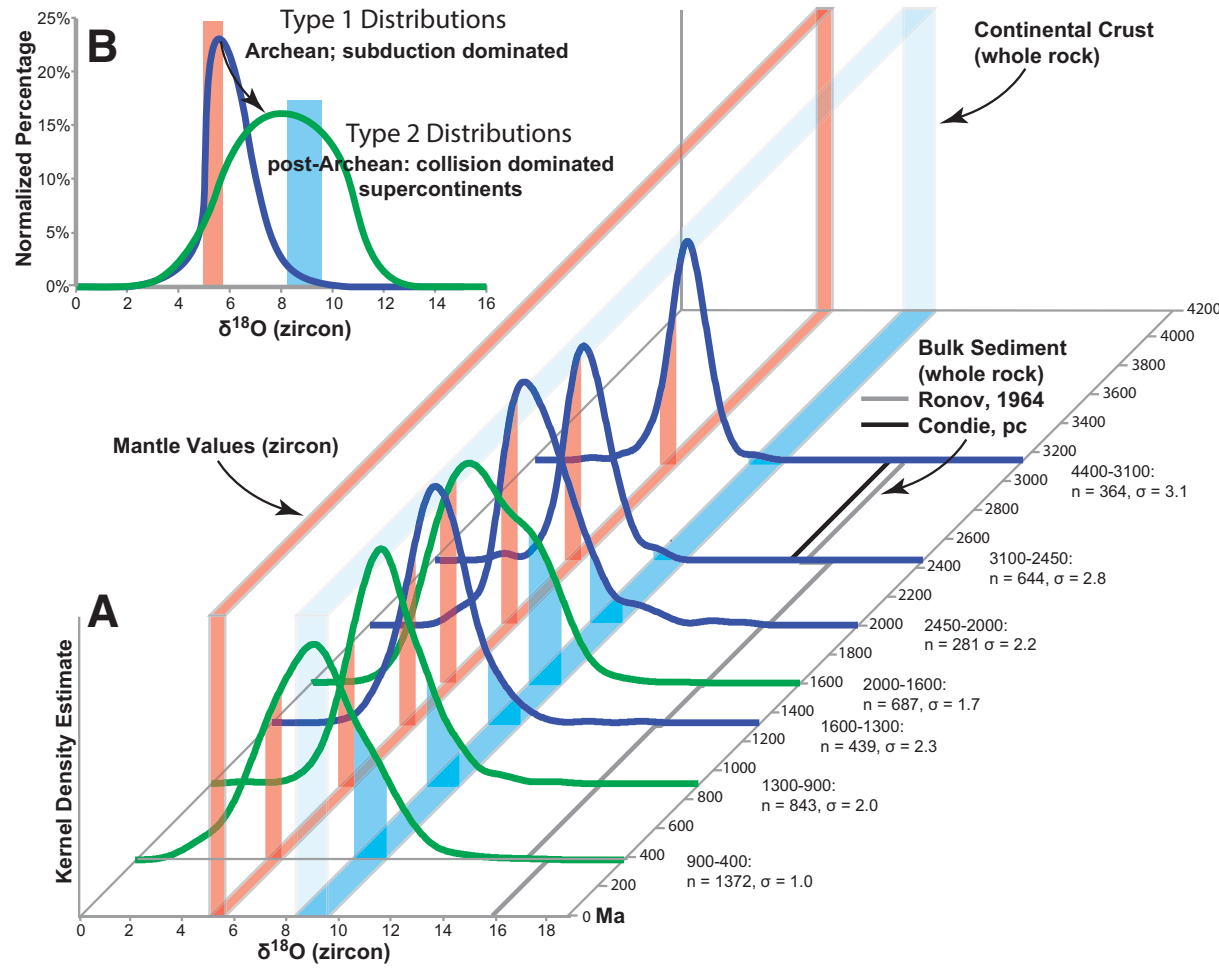

Figure 2. A: Distributions of $\delta^{18} \mathrm{O}$ analyses of zircons normalized to total analyses within specific temporal subdivisions (see text) superimposed on mantle values of Valley et al. (1998). To test sensitivity of our chosen bin widths, boundaries were adjusted \pm 50 m.y.; this had negligible effect on $\delta^{18} \mathrm{O}$ distributions due to small number of analyses near window margins relative to thickness of our chosen windows. Calculation of $\delta^{18} \mathrm{O}$ composition of bulk sediment based on sedimentary models of Ronov (1964) and K. Condie (2014, personal commun.) is discussed in text. B: Schematic diagram of $\delta^{18} \mathrm{O}$ distributions of subductionand collision-dominated temporal subdivisions.

tinued subduction processes led to increased volume and thickness of preserved continental crust and sedimentary differentiation (Ernst, 2009). These developments in Earth's thermomechanical attributes were accompanied by continental collisions, crustal thickening, and an increase in the degree of crustal reworking post-2.5 Ga. The link between increases in the crustal reworking index and the development of supercontinents highlights the role of continental collision in the preferential preservation of peaks of U-Pb crystallization ages in the continental crust (Fig. 1). These conclusions are consistent with other isotopic proxies ( $\mathrm{Zn}$ in banded iron formation, Pons et al., 2013; Sr in seawater, Shields and Veizer, 2002) that are linked to the appearance of large, subaerially exposed continental masses near the ArcheanProterozoic boundary.

The great oxygenation event would have promoted enhanced influx of highly fractionated $\delta^{18} \mathrm{O}$ sedimentary material to basins, material that, when reworked via tectonomagmatic processes, could have contributed to the dramatic increase in zircon $\delta^{18} \mathrm{O}$ between 2.5 and $2.15 \mathrm{Ga}$ (Campbell and Allen, 2008). Interpretations of secular evolutions within this critical age window will benefit especially from future coupled $\mathrm{U}-\mathrm{Pb}$ and $\delta^{18} \mathrm{O}$ analyses in situ in zircons.
Funding from the University of St Andrews and Natural Environment Research Council (grant NE/ J021822/1) is gratefully acknowledged. We thank John Valley for providing the database from Valley et al. (2005), and Tony Fallick, Andy Knoll, Lee Kump, Ruth Robinson, and Martin Whitehouse for helpful comments and stimulating conversations. John Valley, Kent Condie, Gary Ernst, and an anonymous reviewer

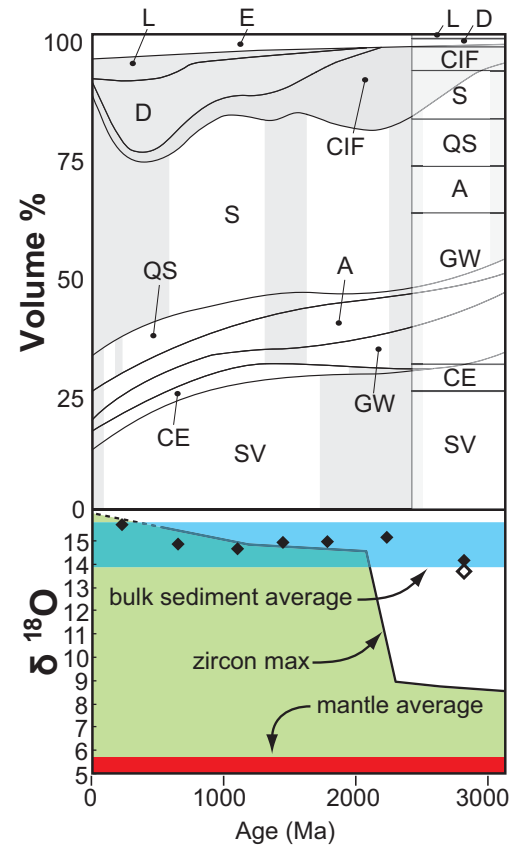

Figure 3. Upper panel: Volume percent of different sedimentary rock types as function of age (from Ronov, 1964). Sedimentary proportions during Archean proposed by $\mathrm{K}$. Condie (2014, personal commun.) are also displayed. Shaded areas are lithologies and time intervals wherein $\delta^{18} \mathrm{O}$ compositions are constrained (Table DR1; see the Data Repository [see footnote 1] for details and references). SV-submarine volcanogenics, CE-continental extrusives, GW-graywacke, A-arkose; QS-quartz sands, Sshale, CIF-cherts and/or iron formations, D-dolomite, L-limestone, E-evaporites. Lower panel: $\delta^{18} \mathrm{O}$ (whole rock) values of bulk sediment using temporal subdivisions described in text superimposed over envelope of maximum zircon $\delta^{18} O$ values within compiled database. Average mantle $\delta^{18} \mathrm{O}: 5.5 \% \circ-$ $5.9 \%$ (Bindeman, 2008). Open diamond is average Archean bulk sediment composition using sedimentary proportions proposed by

K. Condie (2014, personal commun.).

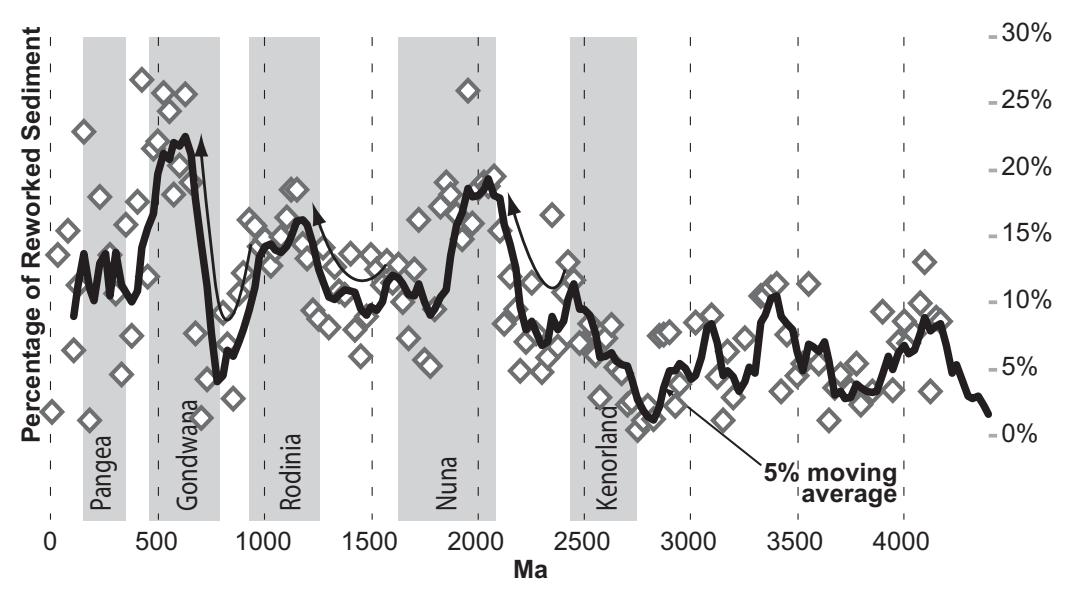

Figure 4. Reworking index plotted through time, calculated by plotting average $\delta^{18} \mathrm{O}$ composition of zircons (in $25 \mathrm{~m}$.y. bins) along univariant mixing line between $\delta^{18} \mathrm{O}$ composition of mantle $(5.5 \%$ ) and calculated average bulk sediment $\delta^{18} \mathrm{O}$ composition $(14.9 \% \circ \pm 1.0 \%, 2 \sigma)$. Note that zircons with low $\delta^{18} \mathrm{O}$ values $(<5.0 \%$ ) are probably due to hydrothermal alteration (Valley et al., 2003). 
provided helpful feedback that improved the clarity and quality of the manuscript.

\section{REFERENCES CITED}

Anderson, T.F., and Arthur, M.A., 1983, Stable isotopes of oxygen and carbon and their application to sedimentologic and paleoenvironmental problems: Stable Isotopes in Sedimentary Geology, v. 10, p. 1-151, doi:10.2110/scn.83.01.0000.

Arndt, N., and Davaille, A., 2013, Episodic Earth evolution: Tectonophysics, v. 609, p. 661-674, doi:10.1016/j.tecto.2013.07.002.

Bindeman, I., 2008, Oxygen isotopes in mantle and crustal magmas as revealed by single crystal analysis: Reviews in Mineralogy and Geochemistry, v. 69 , p. $445-478$, doi:10.2138/rmg .2008.69.12.

Bindeman, I., and Valley, J., 2001, Low- $\delta^{18}$ O rhyolites from Yellowstone: Magmatic evolution based on analyses of zircons and individual phenocrysts: Journal of Petrology, v. 42, p. 14911517, doi:10.1093/petrology/42.8.1491.

Booth, A.L., Kolodny, Y., Chamberlain, C.P., McWilliams, M., Schmitt, A.K., and Wooden, J., 2005, Oxygen isotopic composition and U-Pb discordance in zircon: Geochimica et Cosmochimica Acta, v. 69, p. 4895-4905, doi:10.1016/j .gca.2005.05.013.

Bowman, J.R., Moser, D.E., Valley, J.W., Wooden, J.L., Kita, N.T., and Mazdab, F.K., 2011, Zircon $\mathrm{U}-\mathrm{Pb}$ isotope, $\delta^{18} \mathrm{O}$ and trace element response to $80 \mathrm{~m}$.y. of high-temperature metamorphism in the lower crust: Sluggish diffusion and new records of Archean craton formation: American Journal of Science, v. 311, p. 719-772, doi:10.2475/09.2011.01.

Bradley, D.C., 2008, Passive margins through Earth history: Earth-Science Reviews, v. 91, p. 1-26, doi:10.1016/j.earscirev.2008.08.001.

Bradley, D.C., 2011, Secular trends in the geologic record and the supercontinent cycle: EarthScience Reviews, v. 108, p. 16-33, doi:10.1016/j .earscirev.2011.05.003.

Campbell, I.H., and Allen, C.M., 2008, Formation of supercontinents linked to increases in atmospheric oxygen: Nature Geoscience, v. 1, p. 554-558, doi:10.1038/ngeo259.

Cawood,P.A., Kröner,A., and Pisarevsky, S., 2006, Precambrian plate tectonics: Criteria and evidence: GSA Today, v. 16, no. 7, p. 4-11, doi:10.1130 /GSAT01607.1.

Cawood, P.A., Hawkesworth, C.J., and Dhuime, B., 2013, The continental record and the generation of continental crust: Geological Society of America Bulletin, v. 125, p. 14-32, doi:10.1130/B30722.1.

Cherniak, D.J., and Watson, E.B., 2001, Pb diffusion in zircon: Chemical Geology, v. 172, p. 5-24, doi:10.1016/S0009-2541(00)00233-3.

Condie, K.C., and Kröner, A., 2013, The building blocks of continental crust: Evidence for a major change in the tectonic setting of continental growth at the end of the Archean: Gondwana Research, v. 23, p. 394-402, doi:10.1016/j .gr.2011.09.011.

Condie, K.C., Bickford, M.E., Aster, R.C., Belousova, E., and Scholl, D.W., 2011, Episodic zircon ages, $\mathrm{Hf}$ isotopic composition, and the preservation rate of continental crust: Geological Society of America Bulletin, v. 123, p. 951957, doi:10.1130/B30344.1.

Dhuime, B., Hawkesworth, C.J., Cawood, P.A., and Storey, C.D., 2012, A change in the geodynamics of continental growth 3 billion years ago: Sci- ence, v. 335, p. 1334-1336, doi:10.1126/science .1216066 .

Eiler, J., 2001, Oxygen isotope variations of basaltic lavas and upper mantle rocks: Reviews in Mineralogy and Geochemistry, v. 43, p. 319-364, doi: 10.2138/gsrmg.43.1.319.

Ernst, W.G., 2009, Archean plate tectonics, rise of Proterozoic supercontinentality and onset of regional, episodic stagnant-lid behaviour: Gondwana Research, v. 15, p. 243-253, doi:10.1016 j.gr.2008.06.010.

Gilliam, C., and Valley, J., 1997, Low $\delta^{18} \mathrm{O}$ magma, Isle of Skye, Scotland: Evidence from zircons: Geochimica et Cosmochimica Acta, v. 61, p. 49754981, doi:10.1016/S0016-7037(97)00297-4

Grimes, C.B., Ushikubo, T., John, B.E., and Valley, J.W., 2011, Uniformly mantle-like $\delta^{18} \mathrm{O}$ in zircons from oceanic plagiogranites and gabbros: Contributions to Mineralogy and Petrology, v. 161, p. 13-33, doi:10.1007/s00410-010 -0519-x.

Hawkesworth, C.J., and Kemp, I.S., 2006, The differentiation and rates of generation of the continental crust: Chemical Geology, v. 226, p. 134143, doi:10.1016/j.chemgeo.2005.09.017.

Hawkesworth, C.J., Dhuime, B., Pietranik, A.B., Cawood, P.A., Kemp, A.I.S., and Storey, C.D., 2010, The generation and evolution of the continental crust: Geological Society of London Journal, v. 167, p. 229-248, doi:10.1144/0016 -76492009-072.

Keller, C.B., and Schoene, B., 2012, Statistical geochemistry reveals disruption in secular lithospheric evolution about $2.5 \mathrm{Gyr}$ ago: Nature, v. 485, p. 490-493, doi:10.1038/nature11024.

Knauth, L.P., 2005, Temperature and salinity history of the Precambrian ocean: Implications for the course of microbial evolution: Palaeogeography, Palaeoclimatology, Palaeoecology, v. 219, p. 53-69, doi:10.1016/j.palaeo.2004.10.014.

Kolodny, Y., and Epstein, S., 1976, Stable isotope geochemistry of deep sea cherts: Geochimica et Cosmochimica Acta, v. 40, p. 1195-1209, doi:10.1016/0016-7037(76)90155-1.

Land, L.S., and Lynch, F.L.E.O., 1996, $\delta^{18} \mathrm{O}$ values of mudrocks: More evidence for an ${ }^{18} \mathrm{O}$-buffered ocean: Geochimica et Cosmochimica Acta, v. 60, p. 3347-3352, doi:10.1016/0016-7037(96) 00185-8.

Monani, S., and Valley, J.W., 2001, Oxygen isotope ratios of zircon: Magma genesis of low $\delta^{18} \mathrm{O}$ granites from the British Tertiary Igneous Province, western Scotland: Earth and Planetary Science Letters, v. 184, p. 377-392.

Page, F.Z., Fu, B., Kita, N.T., Fournelle, J., Spicuzza, M.J., Schulze, D.J., Viljoen, F., Basei, M.S., and Valley, J.W., 2007, Zircons from kimberlite: New insights from oxygen isotopes, trace elements, and $\mathrm{Ti}$ in zircon thermometry: Geochimica et Cosmochimica Acta, v. 71, p. 38873903, doi:10.1016/j.gca.2007.04.031.

Perry, E.C., Jr., and Lefticariu, L., 2003, Formation and geochemistry of Precambrian cherts, in Mackenzie, F.T., ed., Sediments, diagenesis, and sedimentary rocks: Treatise on Geochemistry Volume 7: Amsterdam, Elsevier, p. 99 113, doi:10.1016/B0-08-043751-6/07138-3.

Pons, M.-L., Fujii, T., Rosing, M., Quitté, G., Télouk, P., and Albarède, F., 2013, A Zn isotope perspective on the rise of continents: Geobiology, v. 11, p. 201-214, doi:10.1111/gbi.12030.

Rino, S., Komiya, T., Windley, B.F., Katayama, I., Motoki, A., and Hirata, T., 2004, Major episodic increases of continental crustal growth determined from zircon ages of river sands; implications for mantle overturns in the early Precambrian: Physics of the Earth and Planetary Interiors, v. 146, p. 369-394, doi:10.1016/j.pepi .2003.09.024.

Roberts, N.M.W., Slagstad, T., Parrish, R.R., Norry, M.J., Marker, M., and Horstwood, M.S.A., 2013, Sedimentary recycling in arc magmas: Geochemical and U-Pb-Hf-O constraints on the Mesoproterozoic Suldal Arc, SW Norway: Contributions to Mineralogy and Petrology, v. 165, p. 507-523, doi:10.1007/s00410-012-0820-y.

Ronov, A.B., 1964, Common tendencies in the chemical evolution of the Earth's crust, ocean and atmosphere: Geochemistry International, v. 1, p. 713-737.

Shields, G., and Veizer, J., 2002, Precambrian marine carbonate isotope database: Version 1.1: Geochemistry Geophysics Geosystems, v. 3, p. 1-12, doi:10.1029/2001GC000266.

Shimazaki, H., and Shinomoto, S., 2007, A method for selecting the bin size of a time histogram: Neural Computation, v. 19, p. 1503-1527, doi:10.1162/neco.2007.19.6.1503.

Stein, M., and Ben-Avraham, Z., 2007, Mechanism of continental crust growth, in Stevenson, D., ed., Evolution of the Earth: Treatise on Geophysics Volume 9: Amsterdam, Elsevier, p. 171-195.

Stein, M., and Hofmann, A.W., 1994, Mantle plumes and episodic crustal growth: Nature, v. 372, p. 63-68, doi:10.1038/372063a0.

Valley, J.W., Chiarenzelli, J.R., and McLelland, J.M., 1994, Oxygen isotope geochemistry of zircon: Earth and Planetary Science Letters, v. 126, p. 187-206, doi:10.1016/0012-821X (94)90106-6

Valley, J.W., Kinny, P.D., Schulze, D.J., and Spicuzza, M.J., 1998, Zircon megacrysts from kimberlite: Oxygen isotope variability among mantle melts: Contributions to Mineralogy and Petrology, v. 133, p. 1-11, doi:10.1007/s004100050432.

Valley, J.W., Bindeman, I.N., and Peck, W.H., 2003, Empirical calibration of oxygen isotope fractionation in zircon: Geochimica et Cosmochimica Acta, v. 67, p. 3257-3266, doi:10.1016 /S0016-7037(03)00090-5.

Valley, J.W., and 12 others, 2005, 4.4 billion years of crustal maturation: Oxygen isotope ratios of magmatic zircon: Contributions to Mineralogy and Petrology, v. 150, p. 561-580, doi:10.1007 /s00410-005-0025-8.

Van Kranendonk, M.J., and Kirkland, C.L., 2013, Orogenic climax of Earth: The 1.2-1.1 Ga Grenvillian superevent: Geology, v. 41, p. 735738, doi:10.1130/G34243.1.

Veizer, J., and Mackenzie, F., 2003, Evolution of sedimentary rocks, in Mackenzie, F.T., ed., Sediments, diagenesis, and sedimentary rocks: Treatise on Geochemistry Volume 7: Amsterdam, Elsevier, p. 369-407, doi:10.1016/B0-08 -043751-6/07103-6.

Voice, P.J., Kowalewski, M., and Eriksson, K.A., 2011, Quantifying the timing and rate of crustal evolution: Global compilation of radiometrically dated detrital zircon grains: Journal of Geology, v. 119, p. 109-126, doi:10.1086/658295.

Manuscript received 9 December 2013 Revised manuscript received 27 February 2014 Manuscript accepted 28 February 2014

Printed in USA 